\title{
"A COMPARATIVE STUDY OF FINANCIAL ANALYSIS OF CADILA AND TORRENT PHARMACUTICALS IN GUJRAT STATE”
}

\author{
Dr.Bhavsinh M Dodia
}

\begin{abstract}
:
Estimation of any company real worth is made by the earnings which depend on investments, quality goods, competitiveness, expertise, quality management of company, profitability, capital structure and dividend policy, corporate social responsibilities. For investing in any company many people use a comparative analysis or financial performances of last data to make their buy or sell decisions. We do this because we need to examine a current market price is fair or not. Investor should analyse management, product, strategy, economy, financial status and other information will help to choose that invest or not. Here attempt madeto analyze the comparative analysis through analysis of financial performance of 2 pharmaceutical companies by using a ratio analysis.
\end{abstract}

Key words: pharmaceutical company, financial performance, ratios

\section{Introduction:}

The pharmaceutical industry is the part of healthcare sector that deals with medicines. This industry is divided in different field like development, production, and marketing of drugs. These are the interdependent fields of drug manufacturing, drug marketer, and biotechnology companies. Today, drug development relies on the effort of highly trained scientist at universities and private companies. The modern era of drug development originated in the $19^{\text {th }}$ century when scientist learned how to isolate and purify medicine compound and develop large scale manufacturing techniques. As understanding of biology and chemistry improved in the $20^{\text {th }}$ century, the occurrence and severity of such diseases as typhoid fever, poliomyelitis and syphilis were greatly reduced. While many drugs such as quinine and morphine are extended from plant. The pharmaceutical industry has greatly aided medical progress, and many new drugs have been discovered and produced in industrial laboratories. Identify new drug discovery process among the industry. 
Drugs have been produced since the earliest time times. Industrial enterprise for the manufacture of drugs appeared in the late $19^{\text {th }}$ century. Their development becomes especially rapid in the early $20^{\text {th }}$ century after the discovery of synthetic drugs. The manufacture of pharmaceutical developed most rapidly in Germany, Great Britain, and Switzerland. Before World War 2. Germany dominated the world market in many types of drugs. In the 1970,s the production of synthetic pharmaceutical and antibiotics rose sharply in the USA and Great Britain.

Between 1946 and 1950 production was organized for synthetic hormones, insulin, synthetic palavering, caffeine, and other substance a total of more than 50 items. The volume of production of pharmaceutical industry in 1950 was 5 times greater than in 1940, and in 1955 it was 3.1 times greater than in 1950. Between the second half of the 1950 and the mid-1960 many new drugs were introduced.

The main goal of the pharmaceutical industry is to provide drugs that prevent infection, maintain health, and cure disease. This industry directly affected the global population, so a number of international regulatory bodies monitor things like drug safety, patents, quality, and pricing. Here some of the regulatory bodies.

World health organization (WHO)

US food and Drug Administration (FDA)

Medicines and Healthcare Product Regulatory Agency (MHRA)

\section{ORIGINE AND EVALUATION:}

The origin of the earlier drug stores goes back to the middle Ages. The first known drug store was opened by Arabian pharmacists in Baghdad in 754, and it gave way to many more, which soon started operating throughout the medieval Islamic world and eventually medieval Europe. Many of the drug stores in Europe and North America had gradually developed into larger pharmaceutical companies by the19th century

In Britain the expansion of the railway facilities the nationwide distributed of goods and advertising promoting a consumer revolution and the rise of the commercial brand in 1880, Burroughs Well Come \& Co. was established by two American trained pharmacists who introduced American style marketing and manufacturing methods.

During the First World War, Burroughs well come \& co. was alone in able to supply many much needed drugs for military use, and other companies learned from this example. Several including May \& Baker, Nathan \& Sons and British Drug Houses developed research laboratories in the immediate post-war period.

Post war reconstruction and the demand of the new National Health Service further stimulated the pharmaceutical industry. Many new therapies were developed often by rational design based on increased knowledge of the underlying cellular mechanism of drug actions. By the 1970s, this discovery boom was passing to 20 year. in the final decades a drop in the introduction of new drug from 70 to $20 y e a r$. 
This talk with trace the evaluation of modern Pharmaceutical industry from the mid nineteenth century to the final decades of the $20^{\text {th }}$ century. The strong focus on British companies will not be exclusive and a large cast of characters including manufacturing, doctor, scientist and patients will be considered. Several themes will be explored including the roll of innovation in relation to production.

\section{Current scenario:}

Net profit of leading pharmaceutical company in India as of 2020

\begin{tabular}{|c|c|}
\hline Company name & $\begin{array}{c}\text { net profit (in billion } \\
\text { Indian rupees) }\end{array}$ \\
\hline Cipla & 18.88 \\
\hline Glenmark & 16.22 \\
\hline Cadila healthcare & 16.02 \\
\hline Lupin & 15.39 \\
\hline Aurobindo pharma & 15.3 \\
\hline Divis labs & 13.33 \\
\hline Dr.reddys labs & 13.77 \\
\hline Sun pharma & 8.17 \\
\hline Alkem lab & 7.99 \\
\hline Torrent pharma & 7.45 \\
\hline
\end{tabular}

The pharmaceuticals industry in India was valued at US\$33 billion in 2017 and generic drugs accounts for $20 \%$ of global exports in terms of volume, making the country the largest provider of generic medicines globally. According to department of pharmaceuticals, ministry of chemicals and fertilizers, domestic pharmaceutical market turnover reached Rs. 129,015 crore in 2018, growing $9.4 \%$ year on year and export revenue was US\$17.28 billion in FY18 and US\$19.14 billion in FY19. Pune, Hyderabad, Mumbai, baddi, Ahmadabad, vadodara, ankleswar, vapi, Sikkim and Kolkata are major pharmaceuticals hubs of India.

\section{OBJECTIVES OF THE STUDY:}

1. To know about Pharmaceuticals Industry in Gujarat.

2. To know about a financial status of the both company.

3. To review zyndusCadila Healthcare and Torrent Pharmaceuticals Limited.

4. To give suggestions related to study.

\section{DATA ANALYSIS:}

Here, we are doing a financial analysis with the help of ratio to find out a which cadila or torrent pharmaceutical company made more profit and stable.

1. Current ratio 
2. Quick ratio

3. Gross profit ratio

4. Net profit ratio

5. Return on investment ratio

1. Current ratio:

This Ratio establishes a relationship between current assets and current liabilities. The objective of computing this ratio is to measure the safety margin available for short term creditors. This ratio is computed by dividing the current assets and current liabilities. This ratio is usually express as a pure ratio. if the current ratio is 2 or more, its means the firm is adequately liquid and has the ability to meet its current obligations but if the current ratio is less than 2 , it means the firms has difficulty in meeting its current obligations.

\begin{tabular}{|c|c|c|c|c|c|c||}
\hline \multirow{2}{*}{ Year } & \multicolumn{3}{|c|}{ Cadila Healthcare Itd. } & \multicolumn{3}{c|}{ Torrent phar. Itd. } \\
\cline { 2 - 7 } & $\begin{array}{c}\text { Current } \\
\text { assets }\end{array}$ & $\begin{array}{c}\text { Cu. } \\
\text { Liabiliti } \\
\text { es }\end{array}$ & Ratio & $\begin{array}{c}\text { Current } \\
\text { assets }\end{array}$ & $\begin{array}{c}\text { Current } \\
\text { liabilitie } \\
\text { s. }\end{array}$ & Ratio \\
\hline 2014 & 20641 & 15686 & 1.31 & 2672.33 & 1166.94 & 2.29 \\
\hline 2015 & 26973 & 20204 & 1.33 & 2731.63 & 1325.88 & 2.06 \\
\hline 2016 & 29235 & 19203 & 1.52 & 1868.03 & 1339.52 & 1.39 \\
\hline 2017 & 21394 & 30139 & 0.70 & 2223.01 & 1090.51 & 2.03 \\
\hline 2018 & 35514 & 35514 & 1.27 & 1902.15 & 2785.45 & 0.68 \\
\hline Ave. & & & 1.22 & & & 1.69 \\
\hline \hline
\end{tabular}

Source : annual reports and official record of selected pharmaceutical companies.

\section{Current ratio diagram of cadila and torrent}

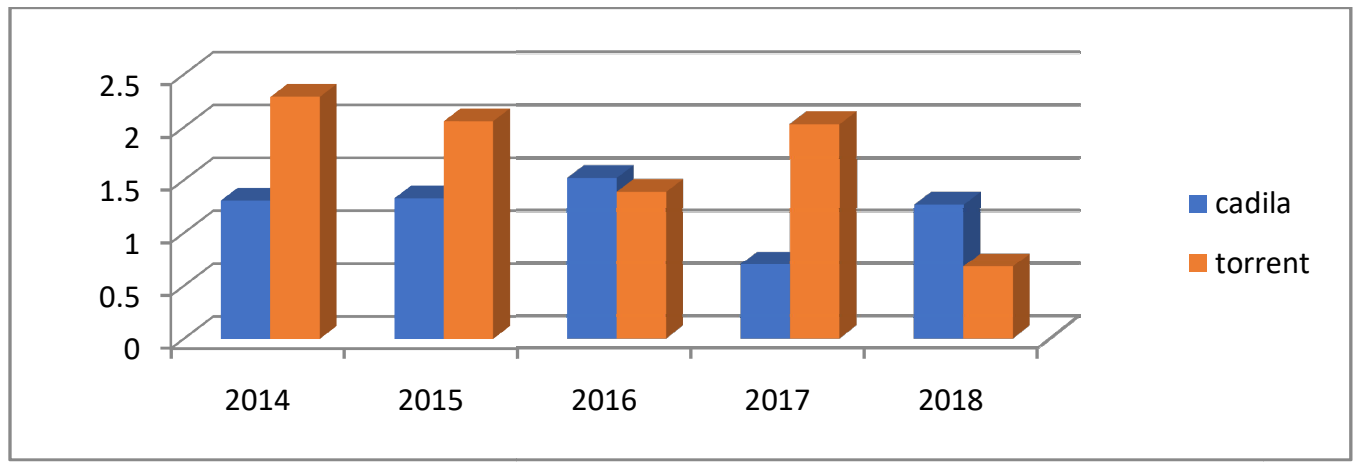

As we can see above both the company's current assets and liabilities are fluctuated in year 2014 to 2018 . 
2. Quick ratio:

Quick Ratio establishes the relationship between the quick assets and current liabilities. The acid test ratio is a more severe and stringent test of a firm's ability to pay its short-term obligations 'as and when they become due. It is considered to be satisfactory. High Acid Test Ratio is an indication that the firm has relatively better position to meet its current obligation in time. On the other hand, a low value of quick ratio exhibiting that the firm's liquidity position is not good.

\begin{tabular}{||c|c|c|c|c|c|c|c|c||}
\hline \multirow{2}{*}{ Year } & \multicolumn{3}{|c|}{ Cadila Healthcare Itd. } & & \multicolumn{3}{c||}{ Torrent phar. Itd. } \\
\cline { 2 - 9 } & $\mathbf{c . a}$ & $\begin{array}{c}\text { Inv.+ } \\
\text { pre.ex } \\
\mathbf{p}\end{array}$ & Ic.I & Ratio & $\begin{array}{c}\text { Current } \\
\text { assets }\end{array}$ & $\begin{array}{c}\text { Inv.+ } \\
\text { pre.ex } \\
\mathbf{p}\end{array}$ & Ic.I & Ratio \\
\hline 2014 & 20641 & 6635 & 15686 & 0.89 & 2672.33 & 694.51 & 1166.94 & 1.69 \\
\hline 2015 & 26973 & 8043 & 20204 & 0.93 & 2731.63 & 781.15 & 1325.88 & 1.47 \\
\hline 2016 & 29235 & 6575 & 19203 & 1.18 & 1868.03 & 970.13 & 1339.52 & 0.69 \\
\hline 2017 & 21394 & 9329 & 30139 & 0.40 & 2223.01 & 1032.29 & 1090.51 & 1.09 \\
\hline 2018 & 35514 & 13207 & 35514 & 0.80 & 1902.15 & 1299.40 & 2785.45 & 0.21 \\
\hline Ave. & & & & 0.84 & & & & 1.03 \\
\hline
\end{tabular}

Source : annual reports and official record of selected pharmaceutical companies.

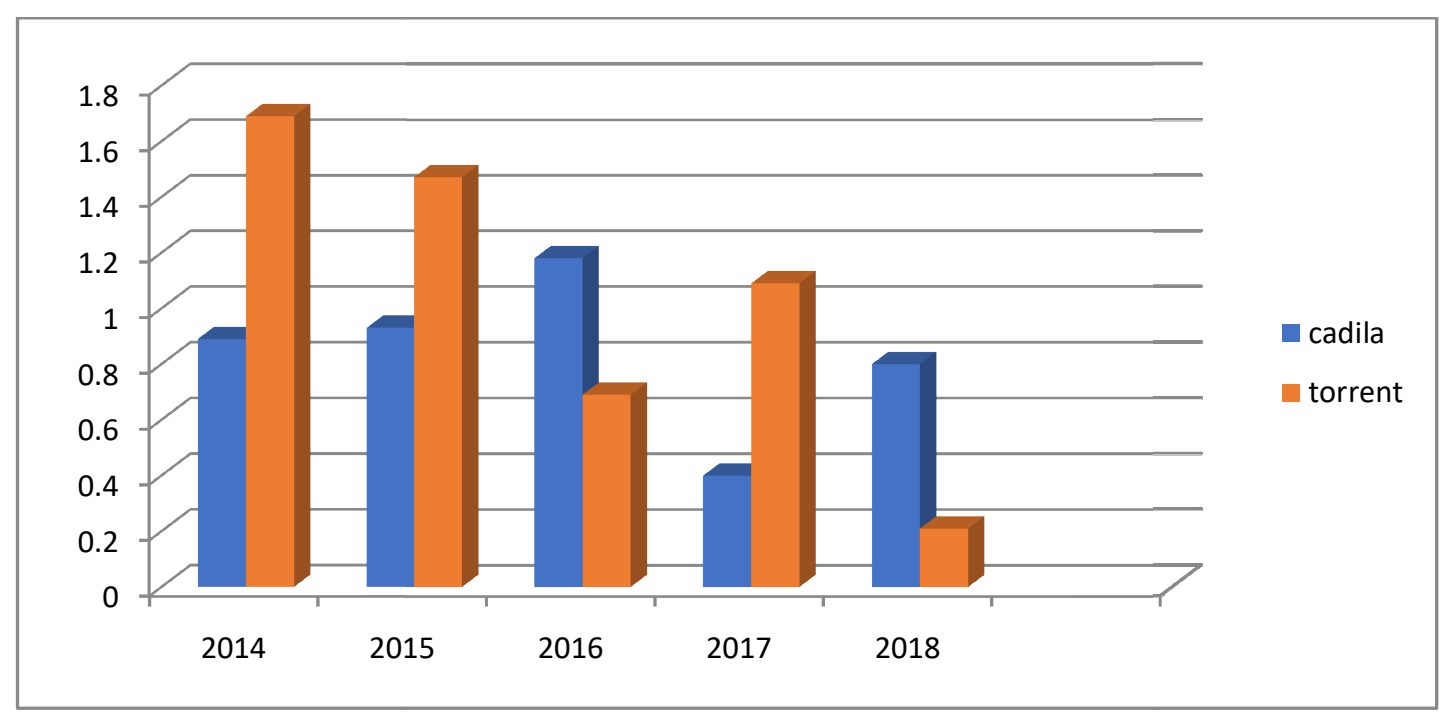

As we can see the average ratio of torrent pharmaceuticals LMT is high so a current position of torrent is better than cadila. 
3. Gross profit ratio:

Gross Profit Ratio established the relationship between gross profit and net sales. This ratio is calculated by dividing the Gross Profit by Sales. It is usually indicated as percentage. Higher Gross Profit Ratio is an indication that the firm has higher profitability. It also reflects the effective standard of performance of firm's business. Higher Gross Profit Ratio will be result of the following factors.

\begin{tabular}{|c|c|c|c|c|c|c||}
\hline \multirow{2}{*}{ Year } & \multicolumn{3}{|c|}{ Cadila Healthcare Itd. } & \multicolumn{3}{c|}{ Torrent phar. Itd. } \\
\cline { 2 - 7 } & G.P & $\begin{array}{c}\text { net } \\
\text { sales }\end{array}$ & Ratio & G.P & $\begin{array}{c}\text { net } \\
\text { sales }\end{array}$ & Ratio \\
\hline 2014 & 1073.10 & 4042.10 & 26.54 & 1037.79 & 3364.87 & 30.84 \\
\hline 2015 & 1676.50 & 5284.40 & 31.72 & 976.30 & 3475.55 & 28.09 \\
\hline 2016 & 2725.00 & 7032 & 38.75 & 2561.76 & 5439.48 & 47.09 \\
\hline 2017 & 893.10 & 3230 & 27.64 & 1224.37 & 4551.45 & 26.88 \\
\hline 2018 & 1790.30 & 5809.90 & 30.81 & 946.01 & 4244.43 & 22.28 \\
\hline Ave. & & & 31.09 & & & 31.03 \\
\hline
\end{tabular}

Source : annual reports and official record of selected pharmaceutical companies.

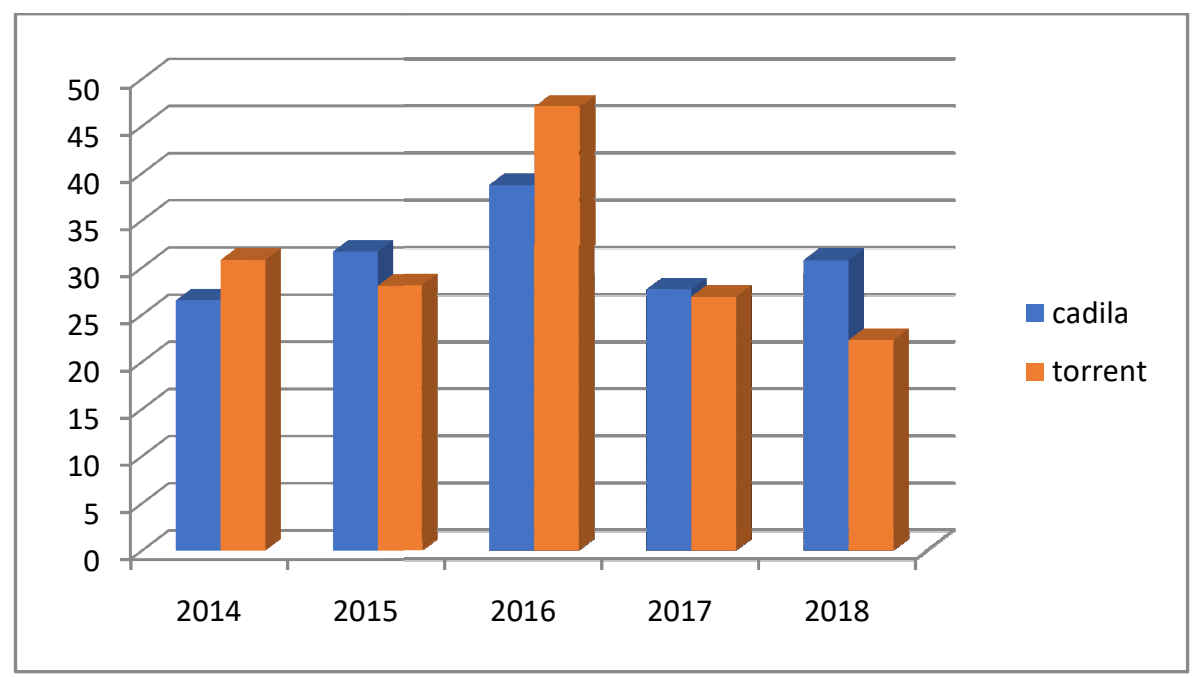

In this table we can see that cadila pharmaceuticals have a higher gross profit ratio as per torrent. 
4. Net profit ratio:

Net Profit Ratio is also termed as Sales Margin Ratio (or) Profit Margin Ratio (or) Net Profit to Sales Ratio. This ratio reveals the firm's overall efficiency in operating the business. Net profit Ratio is used to measure the relationship between net profit and sales. Net profit includes non-operating incomes and profits. NonOperating Incomes such as dividend received, interest on investment, profit on sales of fixed assets, commission received, discount received etc. Profit or Sales Margin indicates margin available after deduction cost of production, other operating expenses, and income tax from the sales revenue. Higher Net Profit Ratio indicates the standard performance of the business concern.

\begin{tabular}{|c|c|c|c|c|c|c|}
\hline \multirow{2}{*}{ Year } & \multicolumn{3}{|c|}{ Cadila Healthcare Itd. } & \multicolumn{3}{c|}{ Torrent phar. Itd. } \\
\cline { 2 - 7 } & $\begin{array}{c}\text { Net } \\
\text { profit }\end{array}$ & $\begin{array}{c}\text { net } \\
\text { sales }\end{array}$ & Ratio & $\begin{array}{c}\text { Net } \\
\text { profit }\end{array}$ & $\begin{array}{c}\text { net } \\
\text { sales }\end{array}$ & Ratio \\
\hline 2014 & 903.60 & 4042.10 & 22.35 & 757.10 & 3364.87 & 22.50 \\
\hline 2015 & 1217.10 & 5284.40 & 24.05 & 612.66 & 3475.55 & 17.62 \\
\hline 2016 & 2037.50 & 7032 & 28.97 & 1703.84 & 5439.48 & 31.32 \\
\hline 2017 & 661.90 & 3230 & 20.48 & 797.60 & 4551.45 & 17.52 \\
\hline 2018 & 1090.80 & 5809.90 & 18.77 & 440.67 & 4244.43 & 10.38 \\
\hline Ave. & & & 22.92 & & & 19.86 \\
\hline \hline
\end{tabular}

Source : annual reports and official record of selected pharmaceutical companies. 


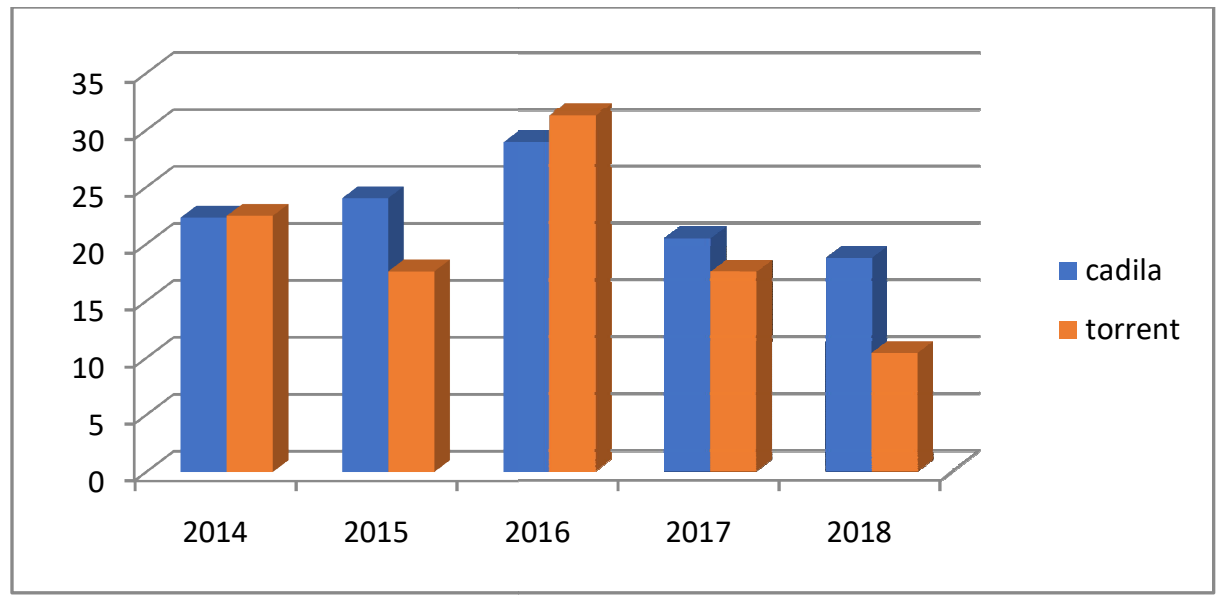

As we can see the cadila healthcare Itd net profit ratio is higher than torrent pharmaceuticals Itd.

5. Return on investment ratio:

This ratio is also called as ROI This ratio measures a return on the owner's or shareholders' investment. This ratio establishes the relationship between net profit after interest and taxes and the owner's investment. Usually this is calculated in percentage.

\begin{tabular}{|c|c|c|c|c|c|c|}
\hline \multirow{2}{*}{ Year } & \multicolumn{3}{|c|}{ Cadila Healthcare Itd. } & \multicolumn{3}{c|}{ Torrent phar. Itd. } \\
\cline { 2 - 7 } & $\begin{array}{c}\text { Net } \\
\text { profit }\end{array}$ & $\begin{array}{c}\text { Share. } \\
\text { Hol. } \\
\text { Fund }\end{array}$ & ratio & $\begin{array}{c}\text { Net } \\
\text { profit }\end{array}$ & $\begin{array}{c}\text { Share } \\
\text { hol. } \\
\text { Fund }\end{array}$ & Ratio \\
\hline 2014 & 903.60 & 3629.90 & 24.89 & 762.34 & 2289.81 & 33.29 \\
\hline 2015 & 1217.10 & 4225.40 & 30.08 & 623.18 & 2705.59 & 23.03 \\
\hline 2016 & 2037.50 & 6276.20 & 32.46 & 1742.99 & 3707.31 & 47.01 \\
\hline 2017 & 661.90 & 6618.30 & 10.00 & 854.22 & 4463.71 & 19.17 \\
\hline 2018 & 1090.80 & 7745.50 & 14.08 & 482.04 & 4556.49 & 10.57 \\
\hline Ave. & & & 22.30 & & & 26.41 \\
\hline
\end{tabular}

Source : annual reports and official record of selected pharmaceutical companies. 


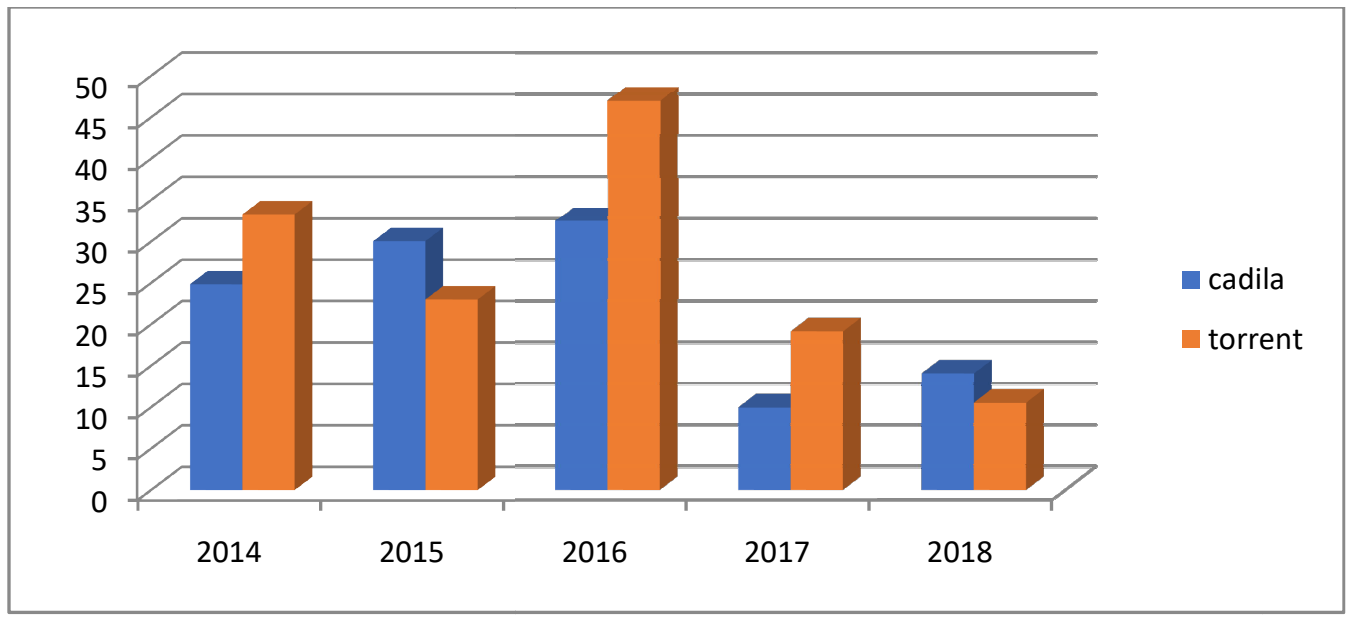

As we can see the torrent pharmaceuticals give higher return on shareholders investment than cadila Itd.

\section{CONCLUSION:}

1. Current ratio of torrent pharmaceuticals is more than cadila thus; cadila has to increase their current assets because of safety margins available for short term creditors.

2. Quick ratio of torrent pharmaceuticals is high than cadila. So, it is advisable to cadila Itd. to Itd. to increase a ratio because it is indication of exhibition of the firm's liquidity position is good.

3. Gross profit ratio of cadila Itd. is high than torrent pharmaceuticals. It means torrent have to increase performance of company.

4. Net profit ratio of cadila Itd. is higher so advisable to torrent pharmaceuticals to increase overall income of business.

5. Return on investment ratio of torrent is higher than cadila healthcare so zyduscadila has to increase their ROI. 


\section{REFERENCES}

1. Khan MY, Jain PK :Financial management, New Delhi: Tata McGraw Hill Publishing Company.

2. Ravi M Kishore - Financial Management - New Delhi - (1996)

3. Bhalla, V. K. Financial Management and Policy, New Delhi: Anmol Publications Pvt. Ltd., 1997.

4. Prasanna Chandra, Financial Management-Theory and Practice, New Delhi:

Tata McGraw Hill Publishing Company, 1984.

5. Pandey I. M., Financial Management, New Delhi: Vikas Publishing House Pvt. Ltd.1983.

6. C.R. Kothari, -Research Methodology, New Age International Publishers, 2nd revised edition 2004.

7. Tulsian P. C., Financial Management, New Delhi, Sultan Chand and Sons, 2009.

8. Aboody $D$ et al (no date) 'Revaluations of fixed assets and future firm performance: Evidence from the UK', in Journal of accounting and economics. Amsterdam: North Holland.

\section{WEBSITES}

1. www.cadilahealthcare.com

2. www.torrrentpharmaceuticals.com

3. www.knowledgeportal.com

4. www.economictimes.com

5. www.myaccountingcourse.com

6. www.investopedia.com

7. www.accountingexplanation.com

\section{Dr.Bhavsinh M Dodia \\ Associate Professor \\ Department of Commerce \& Management, BKNM University, Junagadh}

